\title{
Issue analysis on sexual violence case in sport field reported in the press: Spline function model and text mining application
}

\begin{abstract}
Hyo-Jun Yun*
Korea National Sport University

[Purpose] The purpose of this study is to analyze issues of sexual violence case in sports field reported in the press by using spline function model and text mining. In specific, spline function model is used to measure social interest level based on issue attention cycle theory and figure out the flow of issues by applying text mining. [Methods] Study material is 2,660 news articles reported from January 1, 2017 to December 31, 2019 and press DB(Big Kinds) of Korea Press Foundation is used to collect study material. [Results] Social interest level on sexual violence case in sports field is dramatically increased due to disclosure of Sim player starting from Me Too movement started from the culture and art world. Because of this, as structural problem in sports field arises, social interest level comes to a climax, and then it was founded that the government's countermeasures establishment and special audits by the Ministry of Education were in progress. From the perspective of the issue attention cycle, it has the stages of latent-occurrence-rising-decision-decay-disappearance, but the period from rising to declining is short, so it corresponds to a breaking issue attention cycle. [Conclusion] This study examines the progress of sexual violence case in sports field from rising to disappearance in the perspective of the issue attention cycle. With this incident, the world of sports is establishing sports ethics center and proceeding policies such as Basic Sports Act, and the future studies need to review the effectiveness of this policy.
\end{abstract}

Key words: Sports filed, Sexual violence, Spline function model, Issue attention cycle, Text mining

\section{서 론}

그동안 체육 및 스포츠 영역에서 사회적 이슈는 승부 조 작, 파벌, (성)폭력, 병역특례, 선수 선발의 공정성 등 다양한 주제로 사회적 파장을 일으켜왔다. 특히, 최근에는 쇼트트 랙 국가대표 선수의 고발로 불거진 스포츠계 성폭력 및 폭력

논문 투고일 : 2020.11.17

논문 수정일 : 2021.01.31.

게재 확정일 : 2021.03.16.

* 교신저자 : hyojunyun@hanmail.net

* 이 논문은 2019년 대한민국 교육부와 한국연구재단의 지원을 받아 수행된 연구임(NRF-2019S1A5B5A07087124)
문제는 사회적 파장과 함께 정부는 국가인권위원회를 중심 으로 스포츠 인권 특별조사단을 구성해 스포츠 분야 성폭력 및 폭력을 전수조사를 시행하고 추후 정책 및 제도 개선의 발판을 마련하겠다는 입장을 밝혔다. 아울러 스포츠 분야 폭력 구조의 뿌리로 지적되었던 엘리트 위주 육성 방식의 선 수 육성 체제를 개선하기 위해 민관 합동 스포츠혁신위원회 를 출범시켰다(Lee, 2019).

이처럼 어떤 이슈에 대한 사회적 관심은 정책 결정에 중 요한 역할을 하므로 이슈가 사회적 관심을 집중시키면서 사 회적 이슈로 발전하는 과정을 세밀하게 관찰하는 것과 크게 발전된 사회적 이슈가 정부의 정책 결정으로 연결되는 과정 
을 조명하는 것은 중요하다(Park, 2014).

사회적 이슈가 생성되고 소멸하는 과정을 이슈생존주기 (issue attention cycle) 혹은 이슈관심주기라 한다. Downs 는 1972년 사회적 이슈의 순환 과정을 5단계로 설명하는 이슈생존주기 모형을 발표하였으며 이는 정책의제론 및 저 널리즘 분야에서 활용되는 사례가 많다(Park, 2005). 이슈 생존주기의 5 단계는 다음과 같이 설명된다. 첫 번째 단계는 '사회문제 이전단계'이다. 이 단계는 사회적으로 공공문제 가 발생하지만, 일반 대중에게 관심을 받지 못하는 단계이 다. 그러나 전문가, 이익단체, 이해관계자들이 등장하고 개 입하여 이슈의 사회적 관심도가 형성될 수 있는 단계이다. 두 번째 단계는 '놀라운 발견과 낙관적 열성' 단계이다. 이 단계는 대중들이 갑작스럽게 이슈에 관심을 가지게 되는 단 계이다. 세 번째 단계는 ‘중요한 진척에 필요한 비용 인식'단 계이다. 이 단계는 대중의 관심도가 절정에 도달한 상태로 문제를 해결하기 위해 큰 비용이 필요하다고 인식하는 단계 이다. 일반적으로 이 단계에서 정부는 문제를 해결하려는 노력을 보이는 단계이다(Park, 2002). 네 번째 단계는 '강 한 공공 관심의 점진적 쇠퇴'단계이다. 이 단계는 대중의 관 심도가 서서히 식어가게 되는 단계이며, 다섯 번째 단계는 '문제 이후' 단계이다. 이 단계는 대중들의 관심이 멀어진 단 계로 이슈에 대한 정책들이 시행되고 있어 관심이 멀어지거 나 다른 이슈로 관심이 이전된 단계이다.

이슈생존주기에 대한 이론들은 정책학에서 주로 정책의 의제설정 과정에 관한 연구로 범위가 확정되며(Kim, 2017), 이 과정에서 언론은 중요한 역할을 한다. 언론은 어 떤 이슈에 대한 사회적 관심이 증가하면 이를 지속적으로 보 도하는 속성이 있으며, 언론 보도는 대중들에게 이슈에 관 한 관심을 유지시킴으로써 사회의 정치·사회적 변화를 초래 시키는 역할을 하기 때문이다(Kim, 2006; Kiousis 2003; Molotch \& Lester, 1974; Rose \& Baumgartner, 2013; Schudson, 1978; Soroka, 2002).

그렇다면 이슈에 대한 사회적 관심도를 어떻게 측정할 까? 이슈생존주기 연구를 위해 사회적 관심도 측정은 객관 적인 방법으로 측정되어야 한다는 주장이 꾸준히 제기되어 왔으며(Kim, 2017) 많은 사전연구에서 언론에서 보도되는 양을 기반으로 측정되어왔다(Hilgartner \& Bosk, 1988; MacKuen \& Coombs, 1981; Park, 2005). 그러나 단순 보도량의 변화는 직선적인 관심도 추세로 대중의 관심도 변 화를 설명하기에는 한계점을 가지고 있으므로 이슈생존주
기 이론에 근거한 운형함수모형을 적용하고 있다(Kim, 2017).

사회적 이슈를 분석한 관련된 선행연구들은 살펴보면, 크 게 두 가지로 분류할 수 있다. 첫 번째는 이슈에 대한 사회적 관심도를 계량화하여 이슈관심주기를 분석하는 연구이다 (Kim, 2017; Park, 2005; Park, 2014). 이들 연구는 운형 함수 방법론을 적용하여 Downs(1972)의 5단계 이슈생존 주기별로 분류하고 사회적 관심도 증폭 원인을 파악하고자 하였다. 이는 사회적 관심도를 계량화하여 평가한다는 점에 서 장점이 있지만, 사회적 관심도 증폭 원인을 대부분은 내 용분석 측면에 그치고 있어 증폭 원인을 파악하는데 연구자 의 주관성을 완전히 배제할 수 없다는 단점을 가지고 있다. 두 번째는 텍스트마이닝을 적용하여 사회적 이슈를 분석하 는 연구이다(Lee, 2017; Park et al., 2017; Yang et al., 2016). 이들 연구에서는 사회적 이슈의 원인을 통계적 기법 으로 파악하여 객관적인 원인을 도출해내는 장점이 있지만, 이슈가 발생하는 시점에서부터 관심도가 증폭되는 시점까지 시계열적으로 분류하여 분석하지 못하기 때문에 증폭되는 원인을 정확히 파악하기 어렵다는 단점을 가지고 있다.

체육계 성폭력의 이슈를 분석한 연구로는 JoO \& Lee(2020)는 뉴스, 블로그 등의 자료를 활용하여 체육계 성 폭력에 나타나는 인식을 분석하였다. 이들 연구도 텍스트마 이닝 기법을 활용하여 체육계 성폭력에 대한 이슈를 객관적 으로 분석하였지만 시계열적으로 분류하여 분석하지 않았 다. 이슈가 발전하는 배경에는 관련 사건이 발생하거나 정 책행위자들의 전략 등장과 연관성이 있으므로(Park, 2014) 사회적 관심도의 증가원인을 파악하기 위해서는 관심도가 증가한 시기별 분석이 필요하다. 따라서 이 연구는 최근 체 육계의 사회적 이슈였던 성폭력 사례를 운형함수 모형을 적 용하여 사회적 관심도를 측정하고 텍스트마이닝을 활용하 여 이슈의 발전과정과 관심도의 증가원인을 파악하는 것이 목적이다.

\section{연구방법}

\section{연구절차}

이 연구의 목적을 달성하기 위한 연구절차는 다음 〈Fig $1>$ 과 같다. 첫째, 연구자료를 수집 및 정제하여 최종 연구자 
료를 선정하였다. 둘째, 체육계 성폭력 사례의 사회적 관심 도를 측정하기 위해 운형함수를 모형을 적용하여 이슈생존 주기를 분석하였다. 셋째, 텍스트마이닝을 적용하여 관심도 증폭원인을 알아보기 위해 이슈생존주기별 주요 키워도 산 출과 유산단어 분석을 실시하였다.

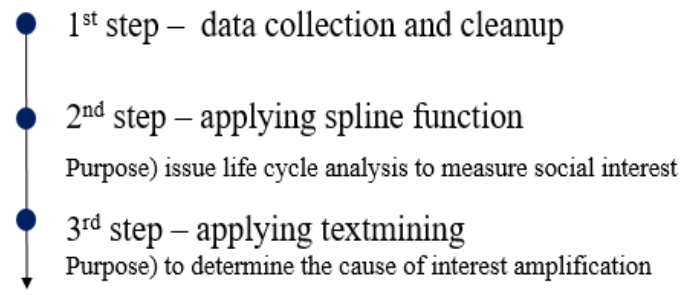

Fig. 1. Research procedure

\section{연구자료}

이 연구의 목적을 달성하기 위해 한국언론진흥재단 언론 $\mathrm{DB}$ (빅카인즈: https://www.bigkinds.or.kr/)에서 검색 되는 뉴스 기사를 연구자료로 선정하였다. 뉴스 기사의 검 색 조건은 다음과 같다. 첫째, 체육, 스포츠, 성폭행, 성폭력 을 키워드로 사용하였다. 이때, 성폭행 혹은 성폭력의 키워 드가 정확히 일치하는 기사와 체육 혹은 스포츠가 포함된 기 사만을 선정하였다. 둘째, 2017년 1월 1일부터 2019년 12 월 31 일까지 기간을 한정하였다. 이와 같은 조건으로 검색 하였을 때, 총 4,861 건의 기사가 검색되었다. 이 중 중복되 는 기사 888건을 제외하였으며, 체육 및 스포츠계 성폭력 (성폭행)을 다루고 있지 않은 기사 1,315 건을 제외하여 최 종적으로 2,660 건의 기사를 연구자료로 선정하였다. 최종 선정된 자료는 분석을 위해 1 주일 간격으로 범주화하였다. 즉, 2017년 1월 1주차부터 2019년 12월 5주차까지 범주 화하였다. 1 주일 간격으로 범주화한 이유는 뉴스 기사의 특 성상 주말에는 상대적으로 보도량이 적게 나타날 수 있다. 따라서 1 일 보도량으로 분석할 경우 결과의 타당성이 떨어 질 수 있음 방지하기 위함이었다. 실제적으로 이 연구에서 선정된 연구자료에서 토요일과 일요일의 보도량은 각각 $3.1 \%, 3.9 \%$ 로 낮게 나타났다.

\section{자료처리}

이 연구에서 적용한 통계적 방법은 크게 두 가지로 나눌
수 있다. 첫째, 운형함수모형이다. 운형함수모형은 체육계 성폭력 사례의 관심도를 측정하기 위해 사용하였다. 이슈에 대한 사회적 관심은 언론이 그 이슈를 다룬 정도로 계량화할 수 있으며 TV나 라디오의 경우 보도 시간으로 뉴스 기사나 잡지는 기사의 게재 면적, 기사 수, 기사의 총글자 수 등으로 계량화된다(Carrol \& McCombs, 2003). 그러나 TV나 라 디오의 경우 보도 시간을 수집하는 데 오랜 시간이 걸리기 때문에 뉴스 기사나 잡지로 활용이 많이 되고 있으며, 신문 기사의 게재 면적으로 측정할 경우 사진까지 포함되기 때문 에 기사의 수나 기사의 총글자 수보다 정확한 측정 방법이 될 수 있다. 최근에는 뉴스 기사가 온라인으로 배포되기 때 문에 측정의 어려움이 있다(Park, 2014). 따라서 이 연구에 서는 한국언론진흥재단의 언론 $\mathrm{DB}$ 를 바탕으로 뉴스 기사 수로 계량화하였다. 그러나 단순 보도량의 변화는 직선적인 관심도 추세로 국민의 관심도 변화를 설명하기에는 한계점을 가지고 있다(Kim, 2017). 따라서 3차원 함수를 기반으로 하는 운형함수모형을 적용하여 국민의 관심도 변화를 파악 하였다. 운형함수모형의 공식은 다음 〈Formula 1〉과 같다.

$$
\begin{aligned}
Y= & a_{1}+b_{1}\left(X-X_{0}\right)+c_{1}\left(X-X_{0}\right)^{2}+d_{1}\left(X-X_{0}\right)^{3} \\
& +\left(d_{2}-d_{1}\right)\left(X-X_{1}\right)^{3} D^{*}+\left(d_{3}-d_{2}\right)\left(X-X_{2}\right)^{3} D^{*} \\
& +\left(d_{4}-d_{3}\right)\left(X-X_{3}\right)^{3} D^{*}+\left(d_{5}-d_{4}\right)\left(X-X_{4}\right)^{3} D^{*}
\end{aligned}
$$

Formula 1. spline function formula

〈Formula 1〉에서 $X_{0}=0, X \geq X_{1}$ 이면 $D^{*}=1$, 나머지 는 $D^{*}=0$ 이고, $X \geq X_{2}$ 이면 $D^{*}=1$, 나머지는 $D^{*}=0$ 이 다. 이와 같이, $X \geq X_{3}$ 이면 $D^{*}=1$, 나머지는 $D^{*}=0$ 이고, $X \geq X_{4}$ 이면 $D^{*}=1$, 나머지는 $D^{*}=0$ 이다(Park, 2014). 이때 $X_{1}, X_{2}, X_{3}, X_{4}$ 등은 이슈주기의 흐름에 있어 급작스 럽게 변화하는 시점으로서 변곡점(spline knot)을 의미한 다. 이러한 변곡점들은 운형함수의 회귀분석에 있어 독립변 수의 수를 결정해 주는데(Park, 2014) 이 연구에서는 주차 별 보도량의 차이를 근거로 변곡점을 설정하였다. 구체적으 로 지난주보다 보도량이 증가하였다면 어떤 사건이 발생한 것으로 간주하였으며 보도량의 증가 기준은 20 개로 설정하 였다. 대부분의 사전연구(Kim, 2017; Park, 2005; Park, 2014)에서는 변곡점을 선정할 때 연구자의 주관에 의해 선 정하지만, 이 연구에서는 연구자의 주관을 배제하려는 노력 의 일환으로 변곡점 수를 고려하여 보도량 증가 기준을 20 개로 설정하였음을 사전에 밝힌다. 
사회적 관심도 증가원인을 파악하기 위해서 이 연구에 서는 텍스트마이닝을 활용하였다. 구체적으로 변곡점 기 간의 언론기사를 활용하여 빈도수 기반으로 주요 키워드 를 산출하였으며, 이때, 키워드는 한국언론진흥재단 언 른 $\mathrm{DB}$ (빅카인즈)에서 제공하는 언론기사의 키워드를 사 용하였다. 그리고 이 연구에서 검색 키워드로 사용된 '체 육', '스포츠', '성폭력', '성폭행' 단어들은 분석에서 제 외하였으며, '문화체육관광부'와 '문체부'와 같이 같은 의미이지만 다르게 표현된 단어들은 하나의 단어로 통합 하였다. 산출된 주요 키워드의 유사단어를 확인하고자 유사단어 분석을 실시하였다. 유사단어를 확인하는 방법 은 다양하지만, 워드 클라우드(Word cloud)와 TF-IDF (Term Frequency-Inverse Document Frequency) 가중치 방법은 단어 간에 얼마나 자주 연관이 되는지의 빈도만을 고려하기 때문에 직관적으로 주제 및 관심 분 야를 찾을 수 있지만, 데이터에 존재하는 대중들의 심리 등을 심층적으로 발취하는데 한계점이 존재한다(Lee et al., 2017). 따라서 이 연구에서 주요 키워드의 유사단어 를 확인하기 위해 Word2vec 분석을 실시하였다. Word2vec는 Mikolov 등(2013)에 의해 처음 제안된 방법으로 인공 신경망을 통해 문장들을 학습하고 문장에 속한 단어들을 파악하여 의미적으로 비슷한 단어끼리 가 까운 벡터공간에 표현해주는 모델이다. 즉, 단어의 순서
가 근접하여 자주 출현할수록 단어들은 유사한 벡터값을 가질 수 있다(Kim et al., 2016).

자료정리를 위해 MS-Excel을 활용하였으며, 운형함수 모형과 텍스트마이닝을 위해 Python 3을 활용하였다.

\section{연구결과}

\section{언론 보도량 변화추이}

다음 〈Fig 2〉는 언론 보도량의 변화추이를 나타낸 것이 다. 그 결과 2019년 1월 2주차에 언론 보도량 529건으로 가장 높게 나타났으며, 2019년 1월 1주차에는 419건으로 두 번째로 높게 나타났다. 2019년 1월 3주차에는 357건으 로 세 번째로 높게 나타났다.

운형함수모형의 독립변수로 활용되는 변곡점은 생애주 기의 흐름에 있어 급작스럽게 변화는 시점을 의미한다. 이 연구에서는 변곡점을 설정하기 위해 전 주차의 보도량보 다 해당 주차의 보도량이 20 개 이상 보도되었을 때 어떠한 사건이 발생한 것으로 판단하여 변곡점의 시기를 나누었 다. 그 결과 7 개의 변곡점이 나타났으며 다음 〈Table 1〉 과 같다.

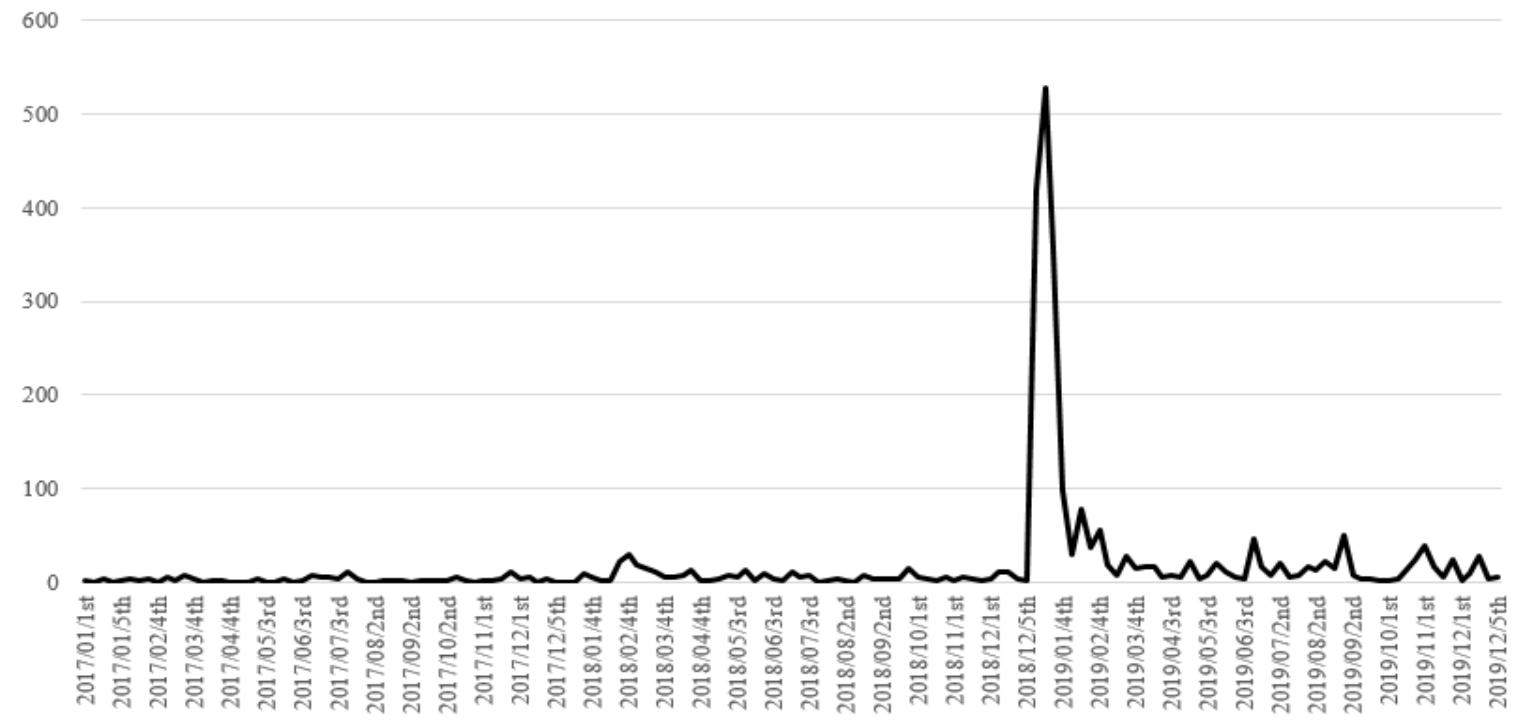

Fig. 2. Trends in the number of press articles 
Table 1. Result of spline knot setting

\begin{tabular}{ccc}
\hline \hline spline knot & the number of press articles & Difference \\
\hline 2018/02/3rd & 22 & 21 \\
$2019 / 01 / 1$ st & 419 & 418 \\
$2019 / 01 / 2$ nd & 529 & 110 \\
$2019 / 02 / 2$ nd & 78 & 49 \\
$2019 / 03 / 3 r d$ & 28 & 20 \\
$2019 / 06 / 4 t h$ & 47 & 43 \\
$2019 / 09 / 1$ st & 51 & 36 \\
\hline \hline
\end{tabular}

Table 2. Result of spline function

\begin{tabular}{cccc}
\hline \hline Independent variable & coef & $\mathrm{t}$ & $\mathrm{p}$ \\
\hline $\mathrm{Z} 1\left(X-X_{0}\right)$ & -4.969 & -2.100 & .037 \\
$\mathrm{Z} 2\left(X-X_{0}\right)^{2}$ & .184 & 2.749 & .007 \\
$\mathrm{Z} 3\left(X-X_{0}\right)^{3}$ & -.002 & -3.250 & .001 \\
$\mathrm{Z} 4(2018 / 02 / 3 \mathrm{rd})$ & .007 & 5.520 & $<.001$ \\
$\mathrm{Z} 5(2019 / 01 / 1 \mathrm{st})$ & -5.937 & -5.630 & $<.001$ \\
$\mathrm{Z} 6(2019 / 01 / 2 \mathrm{nd})$ & 7.971 & 5.297 & $<.001$ \\
$\mathrm{Z}$ (2019/02/2nd) & -2.528 & -3.844 & $<.001$ \\
$\mathrm{Z} 8(2019 / 03 / 3 \mathrm{rd})$ & .489 & 2.070 & .040 \\
Z9(2019/06/4th) & .000 & .001 & .999 \\
Z10(2019/09/1st) & -.003 & -.053 & .958 \\
\hline $\mathrm{R}^{2}$ (adj. $\left.\mathrm{R}^{2}\right)=.428(.388), \mathrm{F}=10.91, \mathrm{p}<.001$ & \\
\hline
\end{tabular}

\section{운형함수를 적용한 이슈생존주기 분석}

운형함수를 적용하여 체육계 성폭력 사례의 회귀방정식 을 만들고 함수 계수들과 설명량을 도출한 결과 다음 〈Table 2〉와 같다.

운형함수 회귀분석결과 모형의 적합도는 $\mathrm{F}=10.91$, $\mathrm{p}<.001$ 수준에서 유의한 것으로 나타났으며, 모형의 설 명력은 $38.8 \%$ 로 나타났다. 회귀분석을 위해 설정한 7 개의 변곡점 중 다음 5 개의 변곡점에서 통계적으로 유 의한 것으로 나타났다. 다음 〈Fig 3〉는 운형함수 회귀방 정식의 추정치에 근거해 도출된 체육계 성폭력 사례의 이슈생존주기이다. 이는 Park(2000)이 주장한 이슈생 존주기 유형 중 속보형의 형태를 나타냈었다.

\section{변곡점별 텍스트마이닝}

운형함수모형에서 통계적으로 유의하게 나타난 변곡점별 뉴스 기사를 대상을 텍스트마이닝을 실시하였다. 우선 빈도 수를 기반으로 변곡점별 주요 키워드를 산출하였다. 다음 〈Table 3〉은 변곡점별 주요 키워드 상위 10 개를 나타낸 것 이며, 〈Table 4〉는 변곡점별 주요 키워드의 연관단어분석 (Word2vec)을 실시한 결과이다. 그 결과 Z4(2018년 2월 3 주차)에서는 '신고', '문체부', '예술', '분야, ‘피해’단어들이

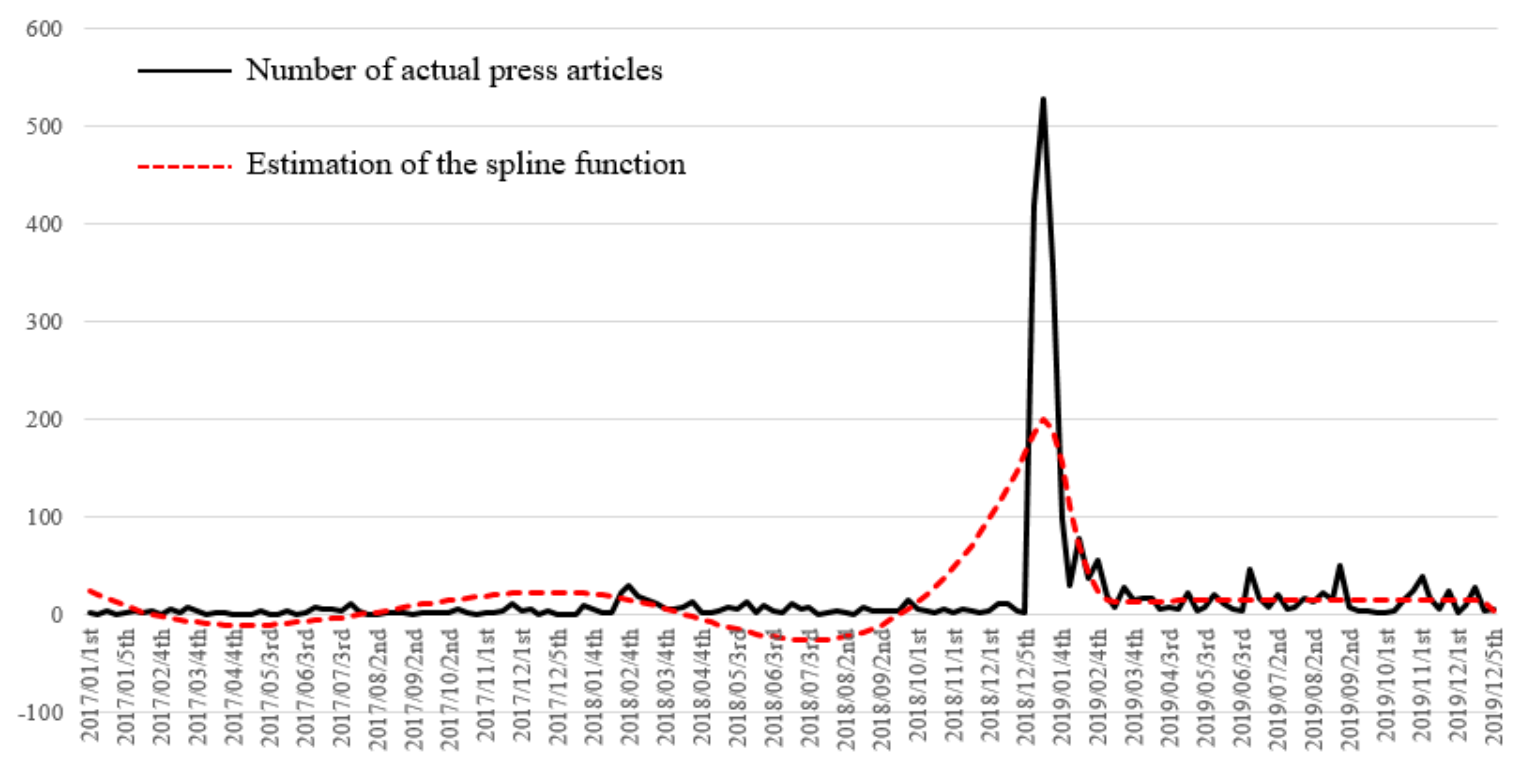

Fig. 3. Estimation of spline function 
Table 3. Keyword by spline knot

\begin{tabular}{|c|c|c|c|c|c|c|c|c|c|c|c|}
\hline \multirow{2}{*}{\multicolumn{2}{|c|}{ category }} & \multicolumn{10}{|c|}{ ranking } \\
\hline & & 1 & 2 & 3 & 4 & 5 & 6 & 7 & 8 & 9 & 10 \\
\hline \multirow{2}{*}{$\mathrm{Z4}$} & Keyword & 신고 & 문체부 & 예술 & 분야 & 피해 & 조사 & 문화 & 성추행 & 피해자 & 미투 \\
\hline & $\mathrm{n}$ & 66 & 62 & 61 & 60 & 56 & 54 & 49 & 45 & 45 & 40 \\
\hline \multirow{2}{*}{$\mathrm{Z} 5$} & Keyword & 선수 & 코치 & 심OO & 폭력 & 국가대표 & 조OO & KOC & 조사 & 사건 & 지도자 \\
\hline & $n$ & 2961 & 1872 & 1623 & 1301 & 1172 & 886 & 820 & 805 & 784 & 740 \\
\hline \multirow{2}{*}{ Z6 } & Keyword & 선수 & 폭력 & 조사 & 코치 & KOC & 피해자 & 대책 & 국가대표 & 사건 & 체육계 \\
\hline & $\mathrm{n}$ & 1968 & 1234 & 924 & 888 & 812 & 668 & 650 & 626 & 623 & 621 \\
\hline \multirow{2}{*}{ Z7 } & Keyword & 선수 & KOC & 국가대표 & 정부 & 인권 & 폭력 & 훈련 & 선수촌 & 문체부 & 올림픽 \\
\hline & $n$ & 224 & 198 & 141 & 137 & 137 & 109 & 99 & 98 & 97 & 93 \\
\hline \multirow{2}{*}{ Z8 } & Keyword & 교육부 & 교수 & 감사 & 학생 & 한국체대 & 결과 & 폭력 & 평가 & 피해자 & 확인 \\
\hline & $\mathrm{n}$ & 169 & 161 & 155 & 150 & 132 & 94 & 91 & 76 & 68 & 68 \\
\hline
\end{tabular}

Table 4. Word2vec result of Keyword by spline knot

\begin{tabular}{|c|c|c|c|c|c|c|}
\hline & \multirow{2}{*}{ category } & \multicolumn{5}{|c|}{ "word similarity ranking } \\
\hline & & 1 & 2 & 3 & 4 & 5 \\
\hline \multirow{10}{*}{$\mathrm{Z} 4$} & 신고 & 창구 & 상담센터 & 센터 & 영화인신문고 & 신설 \\
\hline & 문체부 & 영화 & 분야 & 범위 & 확대 & 신설 \\
\hline & 예술 & 문화 & 대응 & 문체부 & 정부 & 운영 \\
\hline & 분야 & 출판 & 실태 & 대중문화산업 & 미술 & 확대 \\
\hline & 피해 & 상처 & 도움 & 언론 & 정보 & 얼굴 \\
\hline & 조사 & 시범 & 실태 & 실태조사 & 시행 & 미술 \\
\hline & 문화 & 예술 & 대응 & 전반 & 평등 & 신고센터 \\
\hline & 성추행 & 시인 & 고O & 목소리 & 이OO & 성희롱 \\
\hline & 피해자 & 처벌 & 고통 & 용기 & 상처 & 여성 \\
\hline & 미투 & 확산 & 파문 & 운동 & 전반 & 폭로 \\
\hline \multirow{10}{*}{$\mathrm{Z} 5$} & 선수 & 코치 & 심OO & 국가대표 & 피해 & 증언 \\
\hline & 코치 & 심OO & 시절 & 선수 & 국가대표 & 혐의 \\
\hline & 심OO & 코치 & 조OO & 국가대표 & 쇼트트랙 & 상습 \\
\hline & 폭력 & 선수 & 상해 & 수치 & 조OO & 코치 \\
\hline & 국가대표 & 심OO & 코치 & 선수 & 파문 & 쇼트트랙 \\
\hline & 조OO & 심OO & 쇼트트랙 & 게시판 & 상습 & 코치 \\
\hline & KOC & 관련자 & 산하 & 부실 & 권한 & 조사 \\
\hline & 조사 & 전수조사 & 발견 & 실태조사 & 대면 & 주도 \\
\hline & 사건 & 사과 & 2차관 & 법정 & 심OO & 사태 \\
\hline & 지도자 & 실업 & 적발 & 인맥 & 징계 & 학부모 \\
\hline \multirow{10}{*}{ Z6 } & 선수 & 국가대표 & 코치 & 폭로 & 선수생활 & 현직 \\
\hline & 폭력 & 대책 & 구조적 & 국가대표 & 파악 & 선수 \\
\hline & 조사 & 전수조사 & 방법 & 포함 & 실태조사 & 수사 \\
\hline & 코치 & 상습 & 고소 & 중국 & 심OO & 선수 \\
\hline & KOC & 비판 & 회장 & 상실 & 책임론 & 시민단체 \\
\hline & 피해자 & 피해 & 불이익 & 수사 & 심리치료 & 신변보호 \\
\hline & 대책 & 실행 & 브리핑 & 근절 & 그간 & 별관 \\
\hline & 국가대표 & 선수 & 상습폭행 & 폭로 & 장소 & 집중 \\
\hline & 사건 & 사태 & 바람 & 유사 & 진상규명 & 파문 \\
\hline & 체육계 & 악순환 & 의구심 & 일각 & 진단 & 분야 \\
\hline
\end{tabular}




\begin{tabular}{|c|c|c|c|c|c|c|}
\hline \multirow{2}{*}{\multicolumn{2}{|c|}{ category }} & \multicolumn{5}{|c|}{ word similarity ranking } \\
\hline & & 1 & 2 & 3 & 4 & 5 \\
\hline \multirow{10}{*}{$\mathrm{Z7}$} & 선수 & 약속 & 선수촌 & 사과 & 매진 & 남자 \\
\hline & KOC & 대한올림픽위원회 & 분리 & 총회 & 대의원 & 불참 \\
\hline & 국가대표 & 충북 & 개시식 & 훈련 & 남자 & 체조 \\
\hline & 정부 & 종합 & 움직임 & 대한올림픽위원회 & 반발 & 상생 \\
\hline & 인권 & 전문가 & 침해 & 강사 & 상담사 & 특별조사단 \\
\hline & 폭력 & 비위 & 사이 & 근절대책 & 체육계 & 사건 \\
\hline & 훈련 & 개시식 & 충북 & 매진 & 합숙 & 국가대표 \\
\hline & 선수촌 & 충북 & 촌장 & 부촌장 & 사과 & 사기 \\
\hline & 문체부 & 차관 & 불참 & 여가부 & 합동 & 언급 \\
\hline & 올림픽 & 하계 & 남북 & 유치 & 아이스하키 & 도쿄 \\
\hline \multirow{10}{*}{ Z8 } & 교육부 & 감사 & 결과 & 종합 & 한국체대 & 비위 \\
\hline & 교수 & 한국체대 & 전OO & 조OO & 종용 & 수사의뢰 \\
\hline & 감사 & 결과 & 종합 & 교육부 & 특별감사 & 한국체대 \\
\hline & 학생 & 피해 & 정신병원 & 지시 & 주장 & 정도 \\
\hline & 한국체대 & 전OO & 특별감사 & 결과 & 종합 & 교수 \\
\hline & 결과 & 종합 & 감사 & 한국체대 & 교육부 & 특별감사 \\
\hline & 폭력 & 합의 & 코치 & 사건 & 종용 & 피해 \\
\hline & 평가 & 위원 & 서류 & 점수 & 경기실적 & 최종합격 \\
\hline & 피해자 & 합의 & 무마 & 압박 & 쇼트트랙 & 동생 \\
\hline & 확인 & 출결 & 최고경영자 & 여부 & 수료증 & 채점 \\
\hline
\end{tabular}

주요 키워드로 산출되었으며, '신고'는 '창구', '상담센터', '센터', '영화인신문고', '신설' 의 단어와 연관성이 높은 것 으로 나타났다. '문체부'는 '영화', '분야', '범위', ‘확대', '신설'의 단어와 연관성이 높은 것으로 나타났으며, '예술' 은 '문화', '대응', '문체부', '정부', '운영’의 단어와 연관성 이 높은 것으로 나타났다. 이는 문화예술계에서 시작된 미 투 운동이 주요 내용으로 체육계 성폭력 사례는 잠복의 시기 를 거쳐 문화예술계로 시작된 미투 운동을 계기로 수면으로 떠오는 시점이라 할 수 있다.

Z5(2019년 1월 1주차)는 '선수', '코치', '심OO', '폭력', '국가대표'단어들이 주요 키워드로 산출되었으며, '선수'는 '코치', '심OO', ‘국가대표', ‘피해', ‘증언’단어와 연관성이 높은 것으로 나타났다. '코치'는 '심OO', '시절' '선수', '국 가대표', ‘혐의'단어와 연관성이 높은 것으로 나타났으며, '심OO'는 '코치', '조OO', '국가대표', '쇼트트랙', '상습'의 단어와 연관성이 높은 것으로 나타났다. 이는 '쇼트트랙 국 가대표 심OO 선수의 폭로'가 주요 내용으로 체육계 성폭력 사례는 심OO 선수로 폭로로 인해 사회적 관심도는 급격히 상승하였다.

Z6(2019년 1월 2주차)는 '선수', '폭력', '조사', '코치',
‘KOC(대한체육회)' 단어들이 주요 키워드로 산출되었으며, '선수'는 '국가대표', '코치', '폭로', '선수생활', '현직' 단어 와 연관성이 높은 것으로 나타났다. '폭력'단어는 '대책', '구조적', '국가대표', '파악', '선수’ 단어와 연관성이 높은 것으로 나타났으며, '조사'는 '전수조사', '방법', '포함', '실 태조사', '수사'단어와 연관성이 높은 것으로 나타났다. 이 는 심OO 선수의 폭로를 계기로 $\mathrm{KOC}$ 회장의 책임론과 더 불어 체육계의 구조적 문제 제기, 체육계 성폭력 사례의 전 수조사 및 실태조사의 필요성이 제기되는 단계이다.

Z7(2019년 2월 2주차)은 '선수', 'KOC', '국가대표', '정부', '인권'단어들이 주요 키워드로 산출되었으며, '선수' 단어는 '약속', '선수촌, '사과', '매진', '남자' 단어와 연관 성이 높은 것으로 나타났다. 'KOC'는 '대한올림픽위원회', '분리', '총회', '대의원', '불참' 단어와 연관성이 높은 것으 로 나타났으며, '국가대표'는 '충북', '개시식', '훈련', ‘남 자', '체조' 단어와 연관성이 높은 것으로 나타났다. 이는 고 위관계자들의 사과와 더불어 선수 인권을 위해 특별조사단 구성, 인권교육, 전문가 및 상담자 배치 등의 조치가 이루어 지는 단계이다. 
'Z8(2019년 3월 3주차)은 '교육부', '교수', '감사', '학 생', ‘한국체대' 단어들이 주요 키워드로 산출되었으며, '교 육부’는 '감사', '결과', '종합', '한국체대', '비위' 단어와 연 관성이 높은 것으로 나타났다. '교수' 단어는 '한국체대', '전OO', '조OO', ‘종용', ‘수사의뢰’ 단어와 연관성이 높은 것으로 나타났으며, '감사'는 '결과', '종합', '교육부', '특별 감사', ‘한국체대' 단어와 연관성이 높은 것으로 나타났다. 이는 교육부에서의 한국체육대학교와 전OO 특별감사를 통 해 체육계 성폭력 사례의 전수조사가 이루어진 단계이다.

\section{논의 및 결론}

이 연구는 운형함수모형과 텍스트마이닝을 활용하여 언 론 보도에 나타난 체육계 성폭력 사례의 이슈를 분석하는 목 적으로 수행하였다. 구체적으로 운형함수모형을 적용하여 이슈생존주기이론 기반의 사회적 관심도를 측정하고 사회 적 관심도의 증가원인을 파악하기 위해서 텍스트마이닝을 활용하였다. 이 연구에서 나타난 결과를 바탕으로 논의하면 다음과 같다.

이 연구에서 운형함수모형 적용하여 이슈생존주기를 분 석한 결과 5 개의 변곡점에서 통계적으로 유의한 것으로 나 타났으며, 운형함수 회귀방정식의 추정치에 근거하여 관심 도의 변화추이를 파악하면 〈Fig 2〉와 같다. Park(2000)은 우리나라의 100 대 사건을 중심으로 생존주기 유형을 정립 하는 연구를 수행하였으며, 이 연구에서 이슈생존주기를 일 반형, 속보형, 반복형 3가지 유형으로 구분하였다. 일반형 은 Downs(1972)가 주장한 잠복-발생-상승-결정-쇠퇴-소 멸 순서에 따라 변화하는 이슈생존주기를 의미하며, 속보형 은 냄비저널리즘을 설명하는 이슈생존주기로 이슈가 발생 함과 동시에 사회적 관심이 절정에 달하였다가 바로 쇠퇴 및 소멸에 이르는 유형이다. 반복형은 발생-증가-절정-쇠퇴를 거쳤다가 소멸하지 않고 다시 증가-절정-쇠퇴의 주기를 반 복하는 유형을 말한다. 이 연구에서는 토출된 결과(Fig 2)를 보면, Downs(1972)가 주장한 잠복-발생-상승-결정-쇠퇴 -소멸 순서에 따라 변화는 일반형 이슈생존주기의 패턴을 보인다. 그러나 이슈가 발생한 단계에서 상승-결정-쇠퇴에 이르기까지의 시기가 짧다는 것을 고려한다면 $\operatorname{Park}(2000)$ 이 주장한 속보형 이슈생존주기의 형태를 나타내는 것으로 판단된다.
변곡점별 텍스트마이닝 결과를 기반으로 최근 체육계의 사회적 이슈였던 성폭력 사례의 발전전개를 살펴보면, 체육 계 성폭력 사례는 문화예술계에서 시작된 미투 운동을 시발 점으로 이슈가 수면 위로 떠 올랐으며, 심OO 선수의 폭로 로 인해 급격히 상승하였다. 이로 인해 $\mathrm{KOC}$ 회장의 책임론 과 체육계의 구조적 문제가 제기되었으며, 체육계 전반에 걸친 전수조사가 필요하다는 목소리가 나타났다. 이후 관련 고위관계자들의 사과와 선수들의 인권보장을 위해 특별조 사단 구성, 선수 및 지도자 인권교육 활성화, 인권 전문가와 상담가를 기관에 배치되었으며, 교육부에서 한국체육대학 교와 전OO 교수의 특별감사를 실시하는 흐름으로 전개되 었다.

대부분의 사회적 이슈는 언젠가는 사회적 관심으로 멀어 지기 마련이다(Kim, 2017). 그러나 어떤 이슈가 생성되고 소멸하기까지의 과정을 살펴보면, 이슈의 생존 연장과 큰 생존주기를 그리도록 정책행위자들의 전략이 등장하기 마 련이고 이슈와 관련된 돌출사건이 발생하면 큰 생존주기를 그린다(Park, 2014). 최근 쇼트트랙 국가대표 선수 폭로로 인해 불거진 체육계 성폭력 사례 역시 선수들의 인권보장을 위해 특별조사단 구성, 선수 및 지도자 인권교육 활성화, 인 권 전문가와 상담가를 관에 배치 등 정책행위자들의 전략이 등장하였다. 그리고 이 연구에서 운형함수모형의 변곡점으 로 선정한 Z9(2019년 6월 4주차), Z10(2019년 9월 1주차) 는 축구계에서 발생한 성추행 사례와 쇼트트랙에서 발생한 동성 성추행 사례로 돌출사건이 등장하였다. 그럼에도 불구 하고 이슈의 생존주기가 짧은 것은 아쉬운 대목이다.

이 연구는 최근 체육계의 사회적 이슈였던 성폭력 사례를 이슈생존주기 관점에서 이슈가 생성되고 소멸하기까지 과 정을 살펴보기 위해 2017년 1월 1일부터 2019년 12월 31 일까지 언론기사를 활용하였다. 따라서 이 연구의 토출된 결과는 체육계 성폭력 사례를 전반에 걸친 이슈생존주기를 대변하지 못한다. 또한, 이 연구가 수행하는 과정에서 트라 이애슬론종목 성폭력 사례가 발생하면서 다시 한번 사회적 관심도가 증가하였다. 이는 Park(2000)이 이슈생존주기 유 형에서 발생-증가-절정-쇠퇴를 거쳐 다시 증가하는 반복형 의 이슈생존주기를 완전히 배제할 수 없을 것이다.

체육계의 성폭력 문제는 오래전부터 공론화되었고, 2010년부터 대한체육회에서는 2년마다 성폭력실태조사를 진행(Joo \& Lee, 2020)하고 있으며, 2011년에는 선수들의 인권침해를 사전에 예방하고 대처하기 위해 가이드라인을 
개정하였다(Kim \& Kim, 2019). 이처럼 체육계 성폭력 근 절을 위해 국가 차원에서 다양한 정책과 제도적 장치 마련이 모색되었음에도 여전히 체육계 성폭력 문제는 개선되지 못 하였다. 이는 체육계 특유의 폐쇄성, 권력 불평등, 가해자와 피해자 사이의 권력 관계, 엘리트 선수 육성중심의 시스템 문제, 운동 외의 다른 진로가 봉쇄된 구조, 체벌 형태의 폭력 및 성폭력, 신체 접촉을 가장한 성폭력 등으로 보고되고 있 다(Kim \& Kim, 2019). 특히, 운동선수는 지도자의 위력으 로 훈련과정뿐만 아니라 일상적인 상황에서도 반복적으로 성폭력 피해를 겪을 수밖에 없는 구조라는 점에서 더욱더 엄 중한 잣대로 엄격한 대응과 조치가 필요하다. 이번 성폭력 사례에도 국가 차원에서 정책과 제도적 장치 마련이 모색되 었다. 이번 사건을 계기로 출범한 스포츠혁신위원회는 2019년 5월 1차 권고안을 시작으로 1년간 7차례 권고안을 발표하였다. 이는 스포츠윤리센터 설립, 스포츠기본법 추진 등으로 스포츠 문화뿐만 아니라 사회 전체에도 긍정적인 영 향을 미칠 것으로 평가받고 있다. 그러나 지금껏 그래왔듯 이 사건 발생 후 정책 마련에 그치지 말고 다시 한번 내부적 반성과 성찰이 필요하여, 정책이 시행되고 체육계 성폭력 사례의 변화를 주기적으로 분석하고 정책의 실효성을 검토 해 볼 필요가 있다고 판단한다.

이 연구의 결론은 다음과 같다. 첫째, 최근 체육계의 사회 적 이슈였던 성폭력 사례는 이슈생존주기 모형에 근거하였 을 때 속보형이 속한다. 둘째, 이슈의 전개 과정은 문화예술 계에서 시작된 미투 운동을 시작으로 한 선수의 폭로로 인해 이슈의 관심도는 급격히 상승하였다. 이후 체육계의 구조적 문제가 제기되었으며, 정부에서는 체육계 전반에 걸친 전수 조사와 더불어 인권 강화를 위한 정책적 움직임을 보였다.

\section{참고문헌}

Carroll, C. E., \& McCombs, M. (2003). Agenda-setting effects of business news on the public's images and opinions about major corporations. Corporate reputation review, 6(1), 36-46.

Downs, Anthony. (1972). Up and down with ecology-The" issue-attention" cycle". Public interest, 28, 38-50.

Hilgartner, S., \& Bosk, C. L. (1988). The rise and fall of social problems: A public arenas model. American journal of
Sociology, 94(1), 53-78.

Joo, H. C., \& Lee, Y. G. (2020). Analysis of Sexual Violence of Athletes Using Big Data. The Korea Journal of Sport, 18(3), 1105-1114.

Kim, I. S. (2017). A Study on the Inquiry of Conflict - Issue Cycle: In Miryang case. Journal of governance studies, 12(4), 53-82.

Kim, J. D., \& Kim, D. H. (2019). Problems and Solutions of Punishment on Sexual Violence in the World of Sports. The Korean Association of Sports Law, 22(2), 3-24.

Kim, S. G., Cho, H. J., Kang, J. Y. (2016). The Status of Using Text Mining in Academic Research and Analysis Methods. Journal of Information Technology and Architecture, 13(2), 317-329.

Kim S. H. (2006). The Press and Foreign Economic Policy: Politics of U. S. Prestigious Media in the Context of Culture Bite Model. Korean Journal of Journalism \& Communication Studies, 50(5), 30-54.

Lee, C. U., Yoo, K. H., Mun, B. M., \& Bae, S. J. (2017). Informal Quality Data Analysis via Sentimental analysis and Word2vec method. Journal of the Korean Society for Quality Management, 45(1). 117-128.

Lee. D. C. (2019. 2. 25). ‘혁신안 이견’ 문체부-체육회, 남북단 일팀·2032올림픽 '공조'. Yonhap News.

Lee. S. S. (2017). Analysis of Social Issues of the Newspaper Articles on Gyeongju Earthquakes. Journal of Korean Library and Information Science Society, 48(2), 53-72.

MacKuen, M. B., \& Coombs, S. L. (1981). More than news: Media power in public affairs (Vol. 12). sage Publications, inc.

Mikolov, T., Sutskever, I., Chen, K., Corrado, G. S., \& Dean, J. (2013). Distributed representations of words and phrases and their compositionality. In Advances in neural information processing systems, 3111-3119.

Molotch, H., \& Lester, M. (1974). News as purposive behavior: On the strategic use of routine events, accidents, and scandals. American sociological review, 101-112.

Park, H. J, Kim, H. N., \& Hong, Y. J. (2017). A Topic Modeling Analysis on the Major Social Issues of the Students' Human Rights Ordinance in Korea, Asianjournal of education, 18(4), 683-711.

Park, K. M. (2000). Development of Life Cycle Type of Public 
Events: Focused on One Hundred Events. Korean Public Administration Review. 34(3), 143-167.

Park, K. M. (2005). Research on News Paper Attention about Political Issues and Party Preference: In the Case of 17th General Election. Korean Public Administration Review, 39(1), 309-327.

Park, K. M. (2014). A Development and Application of the Measurement Model of Social Attention Increased on Public Issue, Korean Public Administration Quarterly, 26(2), 163-190.

Rose, M., \& Baumgartner, F. R. (2013). Framing the poor: Media coverage and US poverty policy, 1960-2008.
Policy Studies Journal, 41(1), 22-53.

Schudson, Michael. (1978). Discovering the News: A Social History of American Newspapers. New York: Basic.

Soroka, S. N. (2002). Issue attributes and agenda setting by media, the public, and policymakers in Canada. International Journal of Public Opinion Research, 14(3), 264-285.

Yang, S. J., Lee, B. Y., \& Kim., H. W. (2016). A Topic Modeling Approach to the Analysis of Happiness and Unhappiness. Korea Knowledge Management Society, 17(2), 165-185.

\title{
언론 보도에 나타난 체육계 성폭력 사례의 이슈분석: 운형함수모형과 텍스트마이닝 적용
}

\author{
윤효준 \\ 한국체육대학교
}

[목적] 이 연구의 목적은 운형함수모형과 텍스트마이닝을 활용하여 언론 보도에 나타난 체육계 성폭력 사례 의 이슈를 분석하는 것이다. 구체적으로 운형함수모형을 적용하여 이슈생존주기이론 기반의 사회적 관심도를 측정하고 이슈의 흐름을 파악하기 위해 텍스트마이닝을 활용하였다. [방법] 연구자료는 2017년 1월 1일부터 2019년 12월 31일까지 보도된 2660건의 뉴스 기사이며, 연구자료 수집을 위해 언론진흥재단 언론 DB(빅카인 즈)를 활용하였다. 분석을 위해 운형함수모형과 텍스트마이닝의 Word2vec분석을 실시하였다. [결과] 체육계 성폭력 사례는 문화예술계에서 시작된 미투 운동을 시발점으로 심 $\bigcirc \bigcirc$ 선수의 폭로로 인해 사회적 관심도는 급격히 상승하였다. 이로 인해 체육계의 구조적 문제가 제기되면서 사회적 관심도는 절정에 달하고 이후 정부 의 대책 마련과 교육부의 특별감사가 진행되는 흐름으로 전개되는 것으로 나타났다. 이는 이슈생존주기 이론 관점에서 잠복-발생-상승- 결정-쇠퇴-소멸의 단계를 가지고 있으나 상승에서 쇠퇴하기까지 시기가 짧아 속보 형 이슈생존주기에 해당한다. [결론] 이 연구는 체육계 성폭력 사례를 이슈생존주기 관점에서 이슈가 생성되 고 소멸하기까지 과정을 살펴보았다. 이번 사건을 계기로 체육계에서는 스포츠윤리센터 설립, 스포츠기본법 등의 정책을 추진하고 있으며 향후 연구들에서는 이 정책의 실효성에 대해서 검토될 필요성이 있다.

주요어: 체육계, 성폭력, 운형함수모형, 이슈생존주기, 텍스트마이닝 